\title{
River Network Rearrangements in Amazonia Shake Biogeography and Civil Security
}

\author{
Authors

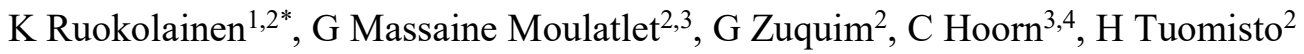

\author{
Affiliations \\ ${ }^{1}$ Department of Geography and Geology, University of Turku, 20014 Turku, Finland. \\ ${ }^{2}$ Department of Biology, University of Turku, 20014 Turku, Finland. \\ ${ }^{3}$ Universidad Regional Amazónica IKIAM, km 7 Via Muyuna, Parroquia Muyuna, Tena, \\ Napo, Ecuador. \\ ${ }^{4}$ Institute for Biodiversity and Ecosystem Dynamics, University of Amsterdam, P.O. Box \\ 94248, 1090 GE Amsterdam, The Netherlands. \\ *Corresponding author. Email: kalle.ruokolainen@utu.fi
}

Key words: avulsion, civil defence, dispersal barrier, flood, Rio Madeira, rain forest, species distribution

\begin{abstract}
The scene for regional biogeography and human settlements in Central Amazonia is set by the river network, which presumably consolidated in the Pliocene. However, we present geomorphological and sediment chronological data showing that the river network has been anything but stable. Even during the last $50 \mathrm{kyr}$, the tributary relationships have repeatedly changed for four major rivers, together corresponding to one third of the discharge of the Amazon. The latest major river capture event converted the Japurá from a tributary of the Rio Negro to a tributary of the Amazon only 1000 years ago. Such broad-scale lability implies that rivers cannot have been as efficient biogeographical dispersal barriers as has generally been assumed, but that their effects on human societies can have been even more profound. Climate change and deforestation scenarios predict increasing water levels during peak floods, which will likely increase the risk of future river avulsions. This may have disastrous consequences for the local human societies, especially in those areas where the current floodplains are at only marginally lower elevations than the nearest water divide. We suggest that the prevailing paradigm of rivers as principal structuring elements of Amazonian biogeography needs to be re-evaluated, and that land use planning and civil risk assessment should take the possibility of river avulsions into account.
\end{abstract}




\section{MAIN TEXT}

\section{Introduction}

Large rivers are the only notable geographical features over vast expanses of relatively flat lowland Amazonian landscape. The ease of fluvial transport and availability of abundant aquatic food resources seem to have always attracted people to the riversides (1-3), despite regular floods, lateral erosion of river banks (4) and, especially in the tectonically active western Amazonia (5-7), occasional avulsions of longer tracts of river channels $(8,9)$.

For animals, large Amazonian rivers have long been regarded as potential dispersal barriers that promote vicariant speciation (10-12). Rivers can be expected to be more important as dispersal barriers in central Amazonia than in western Amazonia both because river channels and floodplains are wider downstream (13) and because the central Amazonian river network supposedly stabilized already in the Pliocene (14-16), giving more time and opportunities for vicariant speciation than in western Amazonia, where rivers are still dynamic due to ongoing tectonic activity $(5-8)$.

Despite numerous examples of Amazonian rivers coinciding with a zone of species compositional or genetic turnover $(11,17-24)$, some of the largest central Amazonian rivers, such as the Juruá and the Purus, have not been found to act as biogeographical barriers (11, $17,25,26)$. In addition, a study focusing on the Madeira river (27) reported that only two of the almost 2000 assessed species of terrestrial animals have distributions consistent with the idea that the Madeira is a dispersal barrier.

In the case of Amazonian fish species, the biogeographical relevance of rivers appears to be even less clear than for terrestrial animals. The recognized biogeographical units are not defined by river catchments but correspond to three geologically circumscribed regions: the Pre-Cambrian shield areas, the central Amazonian lowlands and the still dynamic headwater areas close to the Andes (28-32). Finer biogeographical division following catchment areas of individual tributaries of the Amazon seems justified within the shield areas, but has not given consistent results in central Amazonia $(28,33)$. Indeed, turnover at the species and population levels can occur within a single catchment, often for unknown reasons but sometimes in association with waterfalls or rapids $(34,35)$.

The longer the time that the river network has had its present-day configuration, the larger its effects on biogeography. Among terra firme species (i.e., species of the noninundated areas), the number of vicariant lineages across the rivers should increase with time. Among aquatic species, long-term stability of the river network should promote accumulation of evolutionary specialization to catchment-specific environmental characteristics, such as water chemistry and inundation rhythm. The biogeographical evidence for a dispersal barrier effect of central Amazonian rivers is currently controversial, and a possible explanation for this is that the river network has not been as stable as is presently assumed. If so, the possibility emerges that major avulsions could have happened even during the Holocene, in which case they would be relevant also for the human occupants of Amazonia.

Remarkably young (late Pleistocene to Holocene) datings have been obtained with radiocarbon and OSL (optically stimulated luminescence) methods for some surface sediment samples of central Amazonian terra firme terrain $(36,37)$. The original interpretation was that these deposits represent a vast wetland area that dominated the central Amazonian landscape during the Pleistocene, until the present eastward flow of the Amazon river was established maybe as recently as ca. $30 \mathrm{ka}$ ago $(36,37)$. This scenario is refuted by the geological record of the submarine fan at the mouth of the Amazon $(14,15)$, which shows that sediments of Andean origin have been depositing at the site for at least $9 \mathrm{Ma}$. Therefore, another explanation for the geologically young radiocarbon datings within present-day terra firme is needed. 
It is well-known that Amazonian river channels meander within their floodplains, and that the local erosion and sedimentation processes leave behind recognizable and characteristic topographical patterns (38). Such marks of fluvial activity are also commonly found in the unflooded terraces adjacent to current river floodplains (39). If geologically recent river migrations have extended beyond the known fluvial terraces, this could provide an explanation for the young sediment ages in terra firme. To test this hypothesis, we screened the SRTM digital elevation model (Shuttle Radar Topography Mission) for signs of fluvial morphology over entire central Amazonia.

\section{Results and Discussion}

\section{Signs of fluvial geomorphology in terra firme}

We identified several major rearrangements of the central Amazonian river network (Fig. 2). North of the Amazon, the rivers Japurá and Rio Negro are connected by several relict channels (Fig. 3A and Figs. S1-S7) corresponding to a river with the size and sinuosity of the presentday Japurá. This indicates that the Japurá used to be a tributary of the Rio Negro instead of the Amazon, and that the floodplain of the lower Japurá has swiped over a large area as its mouth has shifted its position along the Rio Negro.

South of the Amazon, there are plenty of relict fluvial marks corresponding to the channel size and geometry of the present-day Juruá, Purus and Madeira (Figs. 1F, 3D and Figs. S8-S14). This suggests that these rivers have migrated widely over the landscape. Both the Juruá and the Madeira have apparently been tributaries of the Purus, with mouths in various separate locations, before becoming tributaries of the Amazon (Fig. 2). In addition, there is evidence of avulsions that have caused large areas of terra firme to pass from one side of a river to the other without changing the tributary arrangements (Figs. 1C, 2, 3C and Figs. S15-S18).

Geomorphological marks of fluvial activity fade with time (Fig. 1B) through rainwater denudation, which makes it possible to estimate their relative ages. The abandoned channels between the Japurá and Rio Negro appear to be the best-preserved ones, suggesting that they are the youngest. Indeed, this connection may have broken as recently as 1000 years ago. Until that time, Rio Negro was not a black water river as we presently know it, but carried a much larger load of sediments, which made the forming of the Mariuá and Anavilhanas archipelagos possible $(40,41)$. The reduction in sediment load was originally assigned to a change in climate (40), but we propose that its main cause was that the white-water river Japurá detached from the black-water Rio Negro and started to carry its sediment load directly into the Amazon. A recent dating of this event is also supported by the account of Condamine (42) from the 1740s, describing that during the high-water season it was possible to travel by boat from Japurá directly to Rio Negro along the river Urubaxi, a connection still identifiable today (Fig. 3A-B).

The most clearly discernable relict floodplain connecting the present-day Madeira and Purus rivers (Figs. 3D and Fig. S12) was probably formed between 13 and $25 \mathrm{ka}$ ago. It is carved within an upper terrace of the Madeira river that has been radiocarbon-dated as $25 \mathrm{ka}$ old (43), and the fluvial traces of the relict floodplain appear more blurred than those of the lower terrace dated to $13 \mathrm{ka}$ (43). In addition, fluvial morphologies in the relict floodplain have a similar degree of clarity as the river meanders on a terrace along Purus, which has been inferred to be at most $19 \mathrm{ka}$ old on the basis of radiocarbon dating (39).

We estimate that none of the relict channels in Fig. 2 is older than $50 \mathrm{ka}$, because clear fluvial morphologies are absent both on the 25-ka-old Madeira terrace (43) and on a 50-ka-old terrace along the main Amazon channel (44). Since the study area is relatively uniform in terms of climate and vegetation structure, it can be assumed that the rate at which fluvial 
traces erode and become visually unrecognizable is roughly the same across the area. Our maximum age estimate of $50 \mathrm{ka}$ is uncertain, but even allowing for a wide error margin it clearly contradicts the notion of a Pliocene (5.3-2.6 Ma) consolidation of the central Amazonian drainage system (16). Instead, our age estimate agrees with the late PleistoceneHolocene dates given by Rossetti et al. (36). We also share the view that tectonically induced tilting is an important factor controlling the fluvial network (45). An indication of tilting is the fact that the terraces are often asymmetrically positioned on one side of a channel only (Fig. 2). Regionally, the tendency is for the lower reaches of rivers to have mostly migrated south or southeastward. For example, the recent shift southwards of the Amazon river itself has left behind a fluvial terrace (Fig. 2) that is ca. $700 \mathrm{~km}$ long and up to $60 \mathrm{~km}$ wide (46). This may be the largest fluvial terrace on Earth.

We propose that the central Amazonian channel migrations reported here (Fig. 2) represent only the most recent phase of a considerably longer dynamism that has prevailed since the Amazon river adopted its present west-to-east flow direction in late MiocenePliocene times $(14,15,47)$. This interpretation is in agreement with the presence of fluvial geomorphologies corresponding to big rivers far from both present and recent relict floodplains (Figs. S19 and S20), and the widely varying OSL datings (ranging from 240 ka to $50 \mathrm{ka}$ ) obtained between the mouths of the Purus and Madeira rivers (44). The recently found Andean signal in the Pliocene to early Pleistocene sediments of the lower Rio Negro (48) also indicates that the present-day fluvial configuration is ephemeral.

\section{Implications for human society}

The switch of the Japurá from a tributary of the Rio Negro to its present position as a tributary of the Amazon, only 1000 years ago, must have had profound consequences for the people who lived along the Rio Negro. The abrupt decrease in sediment load necessarily reduced nutrient levels and decreased productivity in the water, thereby making subsistence more difficult along the Rio Negro below the former mouth of the Japurá. Given that antropogenic dark earth (1) and other remains of human inhabitation are often found in the vicinities of major rivers, it can be postulated that such remains are more abundant along the Urubaxi than is typical for rivers that small.

The very flat overall topography of central Amazonia makes the river channels inherently unstable and prone to avulsions. Tectonic tilting can be expected to continue and lead to avulsions and river capture events also in the future. An avulsion of a major river can have disastrous consequences for human life and property (49), so a risk assessment is in place. One important factor is that climate change and deforestation scenarios predict increasing seasonal variation in river water levels. By the end of this century, discharge during the flood season could increase by $60-90 \%$ in the Juruá, Purus and Madeira rivers and by $25-$ $30 \%$ in the Amazon river (50). An increase in average flood water volume both causes higher floods and increases the erosional-depositional forces of the river, both of which can be expected to make the lateral movement of the channel faster (38).

The site with the highest risk of a major river avulsion in central Amazonia may be close to the city of Humaitá along the Madeira (Fig 4A). Here, the headwaters of the Ipixuna river, a tributary of the Purus, drain a ca. 13-ka-old terrace of the Madeira (43) (Fig. 4A). In the northern part of the terrace, the highway BR-319 crosses the water division between the Ipixuna and Madeira rivers. The road and deforested patches along it record elevations above sea level (asl.) that for the most part are at or below $45 \mathrm{~m}$. This elevation is well below the estimated maximum flood level of $48 \mathrm{~m}$ asl. of the Madeira next to the water division. We derive the estimation from the record flood level of $62.6 \mathrm{~m}$ asl. measured in Porto Velho (51), ca. $320 \mathrm{~km}$ upriver with an average water-surface gradient of $4.2 \mathrm{~cm}$ per kilometer (52). We can conclude that water from the Madeira river occasionally already now flows to the Ipixuna, and hence to Purus. If the floods become more intense, it is possible that the Madeira takes a 
new course and again becomes a tributary of the Purus. This would drastically change water volumes and have immediate consequences for the settlements and cities in the affected areas (lower Purus, lower Madeira and the Amazon river between their mouths, including the city of Manaus).

Another potential place for a major future avulsion is along the lowermost 100-150 $\mathrm{km}$ of the Purus river. This stretch has already moved more than $20 \mathrm{~km}$ to the south-east sometime in the late Pleistocene or Holocene (Fig. S17), following the regional southeastward tendency. Assuming the trend continues, the next avulsion may convert the Purus into a tributary of the Madeira (Fig. 2); the drainage divide between the two rivers is only $4 \mathrm{~km}$ from the edge of the Purus floodplain. Furthermore, if the peak floods increase as predicted, the lower Juruá river might move back to its former channel along the current Jutaí river (Fig. S8). Although major avulsions are infrequent in human timescales, they have been a regular phenomenon across the Amazonian landscape during the late Pleistocene to Holocene times. Therefore, the possibility should be taken into account in the planning of civil defence and land use, including the building of large dams, highways and other infrastructure.

\section{Implications for biogeography and species evolution}

There is no doubt that western Amazonia is tectonically more active than central Amazonia (6). However, recent fluvial processes in the west have largely been restricted to current floodplains and river terraces adjacent to them, whereas in central Amazonia such processes have been much more widespread across present-day terra firme. This implies that rivers may be biogeographically less relevant as dispersal barriers in central than in western Amazonia. Furthermore, the relatively frequent (in evolutionary time scales) avulsions and river captures in central Amazonia can have maintained a selection pressure for floodplain species to tolerate terra firme habitats, and for aquatic species to adapt to changes in water chemistry.

Studies that have tried but failed to find a dispersal barrier effect along the Juruá, Purus and Madeira rivers $(11,17,25-27)$ conform with our geological interpretation of frequent river captures and avulsions during the late Pleistocene-Holocene times. A terra firme species could have gradually, over some tens of thousands of years, dispersed all the way from west of the Juruá to east of the Madeira without any single individual having crossed a major river. On the other hand, it is clear that central Amazonian rivers can act as dispersal barriers. The trunk Amazon river itself must be especially relevant, both because it is so wide and because it has divided lowland Amazonia to northern and southern halves for millions of years in approximately the same location, despite avulsions occasionally having moved pieces of terra firme from one bank of the river to the other (53) (Fig. 3C). The Madeira river has also been found a significant dispersal barrier for several species of birds and other organisms $(11,17-$ $21,54,55)$, and one of the clearest spatial divisions in lowland Amazonian bird species composition follows the Madeira river (56). Consequently, there is no reason to doubt that the Rondônia (east of the Madeira) and Inambari (west of the Madeira) areas of endemism (57) are useful concepts in biogeography, at least for birds. The question is whether that limit is due to the Madeira river itself, or to some other factor. In this context, it is important to note that the Madeira river roughly follows the limit between the geologically young central Amazonian fluvial plain and the much older craton area of the Brazilian shield. Geologically induced habitat differences have been associated with big differences in soil chemistry and plant species composition elsewhere in Amazonia (26, 58-61), and these may induce differences in bird species composition as well (62). The predictions of habitat vs. fluvial control of species distribution can actually be tested along the Madeira river because both geologically young fluvial sediments and considerably older shield geology can be found on the two sides of the river $(63,64)$. At the moment, however, appropriate biological data for this testing is lacking. 
Some of the avulsions we identified took place in a very recent past, which may explain biogeographic patterns that have until now seemed puzzling. The Jaú area of bird endemism (65) is generally drawn such that the Rio Negro and upper Amazon rivers delimit it to the north, east and south, but the western limit has lacked any identifiable dispersal barrier. We propose that the barrier was formed by the lower Japurá when it still flowed to the Rio Negro (Figs. 2, 3A, 3B, S6), a connection that disappeared so recently that the biogeographical pattern it created still lingers. A similar example is the contact zone between two subspecies of the titi monkey Callicebus caligatus (66), found between the Mucuím and Ipixuna rivers. The area lacks any obvious dispersal barriers today, but this is where the Madeira river seems to have had its most recent connection to the Purus (Figs. 2, 3D, S12).

New data on geological history, environmental variation, species distributions and genetics can be expected to clarify the relative roles of rivers and other factors in shaping the past and present of Amazonian biogeography. What is already clear is that when assessing the potential role of a given river, not only its size but also its temporal stability and possible associations with geologically induced habitat differences need to be taken into account.

\section{Materials and Methods}

As a source of elevation data, we used the SRTM digital elevation model (Shuttle Radar Topography Mission), which has $90 \mathrm{~m}$ horizontal and $1 \mathrm{~m}$ vertical resolution. We visually searched for and mapped marks of fluvial topography (Fig. 1) in the entire central Amazonian terra firme lowlands (Fig. 2). Topographical features of presumed fluvial origin were classified into three categories: a) margins of former floodplains, b) traces of river channels, and c) traces of parallel ridges and swales. Each of these is described in more detail below.

The margin of a former floodplain is discernable as a sharp line across which there is a consistent difference in elevation (Fig. 1B, C). Usually on one side of such a line there is an obvious river terrace in which several kinds of fluvial traces are clearly visible, and sometimes a sequence of several terraces adjacent to each other can be seen. In some cases, two sharp and roughly parallel lines can be deduced to delimit a former floodplain, although hardly any fluvial structures are visible between them (Fig. 1C). Such structures have already earlier been interpreted as former river floodplains $(67,68)$, and we suspect that they lack internal fluvial marks because their placement was so short-lived that the river channel did not have time to develop its meanders into full sinuosity.

The most obvious traces of river channels are topographic patterns caused by meanders and oxbow lakes (Fig. 1D). The larger the water discharge of the river, the larger the radius of its meanders (69). Therefore, it is possible to make reasonable estimates of the sizes of past rivers by comparing the fluvial marks they have left behind with those of current rivers. Given that a river channel necessarily represents the locally lowest topographical position, the channels abandoned by major rivers usually serve as drainage outlets for smaller rivers and creeks, which consequently develop their correspondingly smaller meanders within the larger paleomeanders (Fig. 1D). The floodplains of such small rivers inherit the broader-scale sinuosity of the paleomeanders of the larger river. This can be seen in the topography until the outline of the paleochannel fades due to surface denudation.

Alternation between parallel ridges and swales emerges when a meander loop grows laterally by eroding the shore at its outer edge and depositing sediments at its inner edge (Fig. 1E)(38). These scroll-bars are topographically less pronounced than meander loops, so erosion and denudation destroy them more rapidly. However, in some cases the ridge and swale structure can remain visible even after the original topographical variation has faded away. Then the scroll-bars are indicated by numerous parallel streams showing the positions of the past swales (Fig. 1F). 


\section{Supplementary Materials}

Supplementary figures S1-S21 are deposited as a single file in the Open Science Framework in: https://osf.io/uwp9n/

Figs. S1 and S2. An SRTM image A from Central Amazonia and its interpretation B showing marks of river meanders (orange) in terra firme.

Figs. S3-S5. An SRTM image A from Central Amazonia and its interpretation B showing marks of river meanders (orange) and terrace boundaries (blue) in terra firme.

Fig. S6. An SRTM image A from Central Amazonia and its interpretation B showing marks of river meanders (orange) in terra firme.

Figs. S7-S9. An SRTM image A from Central Amazonia and its interpretation B showing marks of river meanders (orange) and terrace boundaries (blue) in terra firme.

Fig. S10. An SRTM image A from Central Amazonia and its interpretation B showing marks of river meanders (orange) in terra firme.

Fig. S11. An SRTM image A from Central Amazonia and its interpretation B showing marks of river meanders (orange) and terrace boundaries (blue) in terra firme.

Figs. S12-S15. An SRTM image A from Central Amazonia and its interpretation B showing marks of river meanders (orange) in terra firme.

Figs. S16-S19. An SRTM image A from Central Amazonia and its interpretation B showing marks of river meanders (orange) and terrace boundaries (blue) in terra firme.

Fig. S20. An SRTM image A from Central Amazonia and its interpretation B showing marks of river meanders (orange) in terra firme.

Fig. S20. Index map for the geographical location of the supplementary figures S1-S20.

\section{References}

1. C. H. McMichael et al., Predicting pre-Columbian anthropogenic soils in Amazonia. Proceedings of the Royal Society B: Biological Sciences. 281, 20132475-20132475 (2014).

2. M. Heckenberger, E. G. Neves, Amazonian Archaeology. Annu. Rev. Anthropol. 38, 251-266 (2009).

3. C. de P. Moraes, E. G. Neves, O ANO 1000: ADENSAMENTO POPULACIONAL, INTERAÇÃO E CONFLITO NA AMAZÔNIA CENTRAL. Amazônica - Revista de Antropologia. 4, 122-148 (2012).

4. R. Kalliola et al., Upper Amazonian channel migration: Implications for vegetation perturbance and succession using bitemporal Landsat MSS images. Naturwissenschaften. 79, 75-79 (1992).

5. M. E. Räsänen, J. S. Salo, R. J. Kalliola, Fluvial perturbance in the western Amazon basin: Regulation by long-term Sub-Andean tectonics. Science. 238, 1398-1401 (1987).

6. C. Hoorn et al., Amazonia Through Time: Andean Uplift, Climate Change, Landscape Evolution, and Biodiversity. Science. 330, 927-931 (2010).

7. L. A. K. Mertes, T. Dunne, L. A. Martinelli, Channel-floodplain geomorphology along the Solimões-Amazon River, Brazil. Geological Society of America Bulletin. 108, 10891107 (1996). 
8. M. H. Pärssinen, J. S. Salo, M. E. Räsänen, River floodplain relocations and the abandonment of Aborigine settlements in the Upper Amazon Basin: A historical case study of San Miguel de Cunibos at the Middle Ucayali River. Geoarchaeology. 11, 345359 (1996).

9. J. F. Dumont, Neotectonics of the Subandes-Brazilian craton boundary using geomorphological data: the Marañon and Beni basins. Tectonophysics. 259, 137-151 (1996).

10. A. R. Wallace, On the monkeys of the Amazon. Proceedings of the Zoological Society of London. 20, 107-110 (1852).

11. C. C. Ribas, A. Aleixo, A. C. R. Nogueira, C. Y. Miyaki, J. Cracraft, A palaeobiogeographic model for biotic diversification within Amazonia over the past three million years. Proc. R. Soc. B. 279, 681-689 (2012).

12. J. M. Ayres, T. H. Clutton-Brock, River Boundaries and Species Range Size in Amazonian Primates. The American Naturalist. 140, 531-537 (1992).

13. J. Haffer, Hypotheses to explain the origin of species in Amazonia. Brazilian Journal of Biology. 68, 917-947 (2008).

14. C. Hoorn et al., The Amazon at sea: Onset and stages of the Amazon River from a marine record, with special reference to Neogene plant turnover in the drainage basin. Global and Planetary Change. 153, 51-65 (2017).

15. E. E. van Soelen et al., A 30 Ma history of the Amazon River inferred from terrigenous sediments and organic matter on the Ceará Rise. Earth and Planetary Science Letters. 474, 40-48 (2017).

16. E. M. Latrubesse et al., The Late Miocene paleogeography of the Amazon Basin and the evolution of the Amazon River system. Earth-Science Reviews. 99, 99-124 (2010).

17. A. M. Fernandes, M. Wink, A. Aleixo, Phylogeography of the chestnut-tailed antbird (Myrmeciza hemimelaena) clarifies the role of rivers in Amazonian biogeography. Journal of Biogeography. 39, 1524-1535 (2012).

18. M. Ferreira, A. Aleixo, C. C. Ribas, M. P. D. Santos, Biogeography of the Neotropical genus Malacoptila (Aves: Bucconidae): the influence of the Andean orogeny, Amazonian drainage evolution and palaeoclimate. Journal of Biogeography. 44, 748-759 (2017).

19. A. M. Fernandes, J. Gonzalez, M. Wink, A. Aleixo, Multilocus phylogeography of the Wedge-billed Woodcreeper Glyphorynchus spirurus (Aves, Furnariidae) in lowland Amazonia: Widespread cryptic diversity and paraphyly reveal a complex diversification pattern. Molecular Phylogenetics and Evolution. 66, 270-282 (2013).

20. A. M. Fernandes, M. Wink, C. H. Sardelli, A. Aleixo, Multiple speciation across the Andes and throughout Amazonia: the case of the spot-backed antbird species complex ( Hylophylax naevius / Hylophylax naevioides ). Journal of Biogeography. 41, 1094-1104 (2014).

21. C. C. Ribas, R. Gaban-Lima, C. Y. Miyaki, J. Cracraft, Historical biogeography and diversification within the Neotropical parrot genus Pionopsitta (Aves: Psittacidae). Journal of Biogeography. 32, 1409-1427 (2005). 
22. L. Y. Pomara, K. Ruokolainen, K. R. Young, Avian species composition across the Amazon River: the roles of dispersal limitation and environmental heterogeneity. Journal of Biogeography. 41, 784-796 (2014).

23. J. W. Lynch Alfaro et al., Biogeography of squirrel monkeys (genus Saimiri): Southcentral Amazon origin and rapid pan-Amazonian diversification of a lowland primate. Molecular Phylogenetics and Evolution. 82, 436-454 (2015).

24. E. D. Schultz et al., Systematics and biogeography of the Automolus infuscatus complex (Aves; Furnariidae): Cryptic diversity reveals western Amazonia as the origin of a transcontinental radiation. Molecular Phylogenetics and Evolution. 107, 503-515 (2017).

25. M. N. F. da Silva, J. L. Patton, Molecular phylogeography and the evolution and conservation of Amazonian mammals. Molecular Ecology. 7, 475-486 (1998).

26. H. Tuomisto et al., A compositional turnover zone of biogeographical magnitude within lowland Amazonia. J. Biogeogr. 43, 2400-2411 (2016).

27. S. J. Santorelli, W. E. Magnusson, C. Deus, Most species are not limited by an Amazonian river postulated to be a border between endemism areas. Scientific Reports. 8, 2294 (2018).

28. F. C. P. Dagosta, M. de Pinna, F. C. P. Dagosta, M. de Pinna, Biogeography of Amazonian fishes: deconstructing river basins as biogeographic units. Neotropical Ichthyology. 15 (2017), doi:10.1590/1982-0224-20170034.

29. J. S. Albert et al., Aquatic Biodiversity in the Amazon: Habitat Specialization and Geographic Isolation Promote Species Richness. Animals. 1, 205-241 (2011).

30. R. Abell et al., Freshwater Ecoregions of the World: A New Map of Biogeographic Units for Freshwater Biodiversity Conservation. BioScience. 58, 403-414 (2008).

31. J. S. Albert, T. P. Carvalho, in Historical biogeography of Neotropical freshwater fishes. (University of California Press, Los Angeles, 2011; http://www.jstor.org/stable/10.1525/j.ctt1pp29c.11), pp. 119-136.

32. F. C. T. Lima, A. C. Ribeiro, in Historical Biogeography of Neotropical Freshwater Fishes (University of California Press, Los Angeles, ed. 1, 2011; http://www.jstor.org/stable/10.1525/j.ctt1pp29c), pp. 145-164.

33. N. Hubert, J.-F. Renno, Historical biogeography of South American freshwater fishes. Journal of Biogeography. 33, 1414-1436 (2006).

34. W. Gravena, I. P. Farias, M. N. F. da Silva, V. M. F. da Silva, T. Hrbek, Looking to the past and the future: were the Madeira River rapids a geographical barrier to the boto (Cetacea: Iniidae)? Conserv Genet. 15, 619-629 (2014).

35. V. N. Machado, S. C. Willis, A. S. Teixeira, T. Hrbek, I. P. Farias, Population genetic structure of the Amazonian black flannelmouth characin (Characiformes, Prochilodontidae: Prochilodus nigricans Spix \&amp; Agassiz, 1829): contemporary and historical gene flow of a migratory and abundant fishery species. Environ Biol Fish. 100, $1-16$ (2017).

36. D. F. Rossetti, P. Mann de Toledo, A. M. Góes, New geological framework for Western Amazonia (Brazil) and implications for biogeography and evolution. Quaternary Research. 63, 78-89 (2005). 
37. D. F. Rossetti et al., Mid-Late Pleistocene OSL chronology in western Amazonia and implications for the transcontinental Amazon pathway. Sedimentary Geology. 330, 1-15 (2015).

38. J. Salo et al., River dynamics and the diversity of Amazon lowland forest. Nature. 322, 254-258 (1986).

39. E. M. Latrubesse, T. Kalicki, Late Quaternary paleohydrological changes in the upper Purus basin, southwestern Amazonia, Brazil. Zeitschrift für Geomorphologie.

Supplement 129, 41-59 (2002).

40. E. M. Latrubesse, E. Franzinelli, The late Quaternary evolution of the Negro River, Amazon, Brazil: Implications for island and floodplain formation in large anabranching tropical systems. Geomorphology. 70, 372-397 (2005).

41. E. Franzinelli, H. Igreja, Modern sedimentation in the Lower Negro River, Amazonas State, Brazil. Geomorphology. 44, 259-271 (2002).

42. J. Pinkerton, A General Collection of the Best and Most Interesting Voyages and Travels in All Parts of the World: Many of which are Now First Translated Into English;

Digested on a New Plan (Longman, Hurst, Rees, and Orme ... and Cadell and Davies, 1813).

43. D. F. Rossetti et al., Late Quaternary fluvial terrace evolution in the main southern Amazonian tributary. CATENA. 116, 19-37 (2014).

44. E. Gonçalves Júnior Senna, E. A. A. Soares, S. H. Tatumi, M. Yee, J. C. R. Mittani, Pleistocene-Holocene sedimentation of Solimões-Amazon fluvial system between the tributaries Negro and Madeira, Central Amazon. Brazilian Journal of Geology. 46, 167 180 (2016).

45. D. F. Rossetti, The role of tectonics in the late Quaternary evolution of Brazil's Amazonian landscape. Earth-Science Reviews. 139, 362-389 (2014).

46. T. C. Bertani, Sensoriamento remoto e caracterização morfológica no baixo rio Solimões, com análise de suas rias fluviais (INPE, São José dos Campos, 2015; http://urlib.net/8JMKD3MGP3W34P/3L46AM8), PhD thesis.

47. J. Figueiredo, C. Hoorn, P. van der Ven, E. Soares, Late Miocene onset of the Amazon River and the Amazon deep-sea fan: Evidence from the Foz do Amazonas Basin. Geology. 37, 619-622 (2009).

48. E. A. A. Soares et al., Sedimentology and Palynostratigraphy of a Pliocene-Pleistocene (Piacenzian to Gelasian) deposit in the lower Negro River: Implications for the establishment of large rivers in Central Amazonia. Journal of South American Earth Sciences (2017), doi:10.1016/j.jsames.2017.08.008.

49. R. Slingerland, N. D. Smith, River Avulsions and their deposits. Annual Review of Earth and Planetary Sciences. 32, 257-285 (2004).

50. M. Guimberteau et al., Impacts of future deforestation and climate change on the hydrology of the Amazon Basin: a multi-model analysis with a new set of land-cover change scenarios. Hydrology and Earth System Sciences. 21, 1455-1475 (2017). 
51. L. B. L. Santos et al., An RS-GIS-Based ComprehensiveImpact Assessment of FloodsA Case Study in Madeira River, Western Brazilian Amazon. IEEE Geoscience and Remote Sensing Letters. 14, 1614-1617 (2017).

52. E. Latrubesse, Patterns of anabranching channels: The ultimate end-member adjustment of mega rivers. Geomorphology. 101, 130-145 (2008).

53. O. L. Ribeiro et al., Controle tectônico na planície do Rio Solimões, região de Coari (AM), a partir de análise em imagens ópticas e dados SRTM. Anais XIV Simpósio Brasileiro de Sensoriamento Remoto, 3301-3308 (2009).

54. R. G. Dias-Terceiro et al., A Matter of Scale: Historical and Environmental Factors Structure Anuran Assemblages from the Upper Madeira River, Amazonia. Biotropica. 47, 259-266 (2015).

55. M. B. de C. Godinho, F. R. Da Silva, The influence of riverine barriers, climate, and topography on the biogeographic regionalization of Amazonian anurans. Scientific Reports. 8, 3427 (2018).

56. U. Oliveira, M. F. Vasconcelos, A. J. Santos, Biogeography of Amazon birds: rivers limit species composition, but not areas of endemism. Scientific Reports. 7, 2992 (2017).

57. J. Cracraft, Historical biogeography and patterns of differentiation within the South American avifauna: Areas of endemism. Ornithological Monographs, 49-84 (1985).

58. H. Tuomisto, K. Ruokolainen, M. Aguilar, A. Sarmiento, Floristic patterns along a 43$\mathrm{km}$ long transect in an Amazonian rain forest. Journal of Ecology. 91, 743-756 (2003).

59. K. J. Salovaara, G. G. Cárdenas, H. Tuomisto, Forest classification in an Amazonian rainforest landscape using pteridophytes as indicator species. Ecography. 27, 689-700 (2004).

60. M. A. Higgins et al., Geological control of floristic composition in Amazonian forests. Journal of Biogeography. 38, 2136-2149 (2011).

61. H. Tuomisto, Interpreting the biogeography of South America: Commentary. Journal of Biogeography. 34, 1294-1295 (2007).

62. L. Y. Pomara, K. Ruokolainen, H. Tuomisto, K. R. Young, Avian composition co-varies with floristic composition and soil nutrient concentration in Amazonian upland forests. Biotropica. 44, 545-553 (2012).

63. IBGE, Estado do Amazonas - Geologia (2010), (available at https://mapas.ibge.gov.br/tematicos/geologia).

64. IBGE, Estado de Rondônia - Geologia (2006), (available at https://mapas.ibge.gov.br/tematicos/geologia).

65. S. H. Borges, J. M. C. Da Silva, A New Area of Endemism for Amazonian Birds in the Rio Negro Basin. The Wilson Journal of Ornithology. 124, 15-23 (2012).

66. J. E. Serrano-Villavicencio, R. L. Vendramel, G. S. T. Garbino, Species, subspecies, or color morphs? Reconsidering the taxonomy of Callicebus Thomas, 1903 in the PurusMadeira interfluvium. Primates. 58, 159-167 (2017). 
67. E. H. Hayakawa, D. F. Rossetti, M. M. Valeriano, Applying DEM-SRTM for reconstructing a late Quaternary paleodrainage in Amazonia. Earth and Planetary Science Letters. 297, 262-270 (2010).

68. E. H. Hayakawa, D. F. Rossetti, Late quaternary dynamics in the Madeira river basin, southern Amazonia (Brazil), as revealed by paleomorphological analysis. Anais da Academia Brasileira de Ciências. 87, 29-49 (2015).

69. R. A. Callander, River meandering. Annual Review of Fluid Mechanics. 10, 129-158 (1978).

\section{Acknowledgments}

We thank Dilce Rossetti for insightful discussions during the preparation of this manuscript and Kyle Harms and Florian Wittman for constructive comments on the manuscript. Funding from the Academy of Finland (grant 273737 to H.T. and grant 296406 to Risto Kalliola) and the University of Turku Graduate School (grant to G.M.M.) is gratefully acknowledged. K.R., H.T. and G.M.M conceived the original idea; K.R., G.M.M, G.Z., and H.T. collected the data; K.R., G.M.M. and G.Z. led the writing with H.T. and C.H. providing comments, edits and reviewing. All authors have checked and approved the paper and Supplementary Materials 


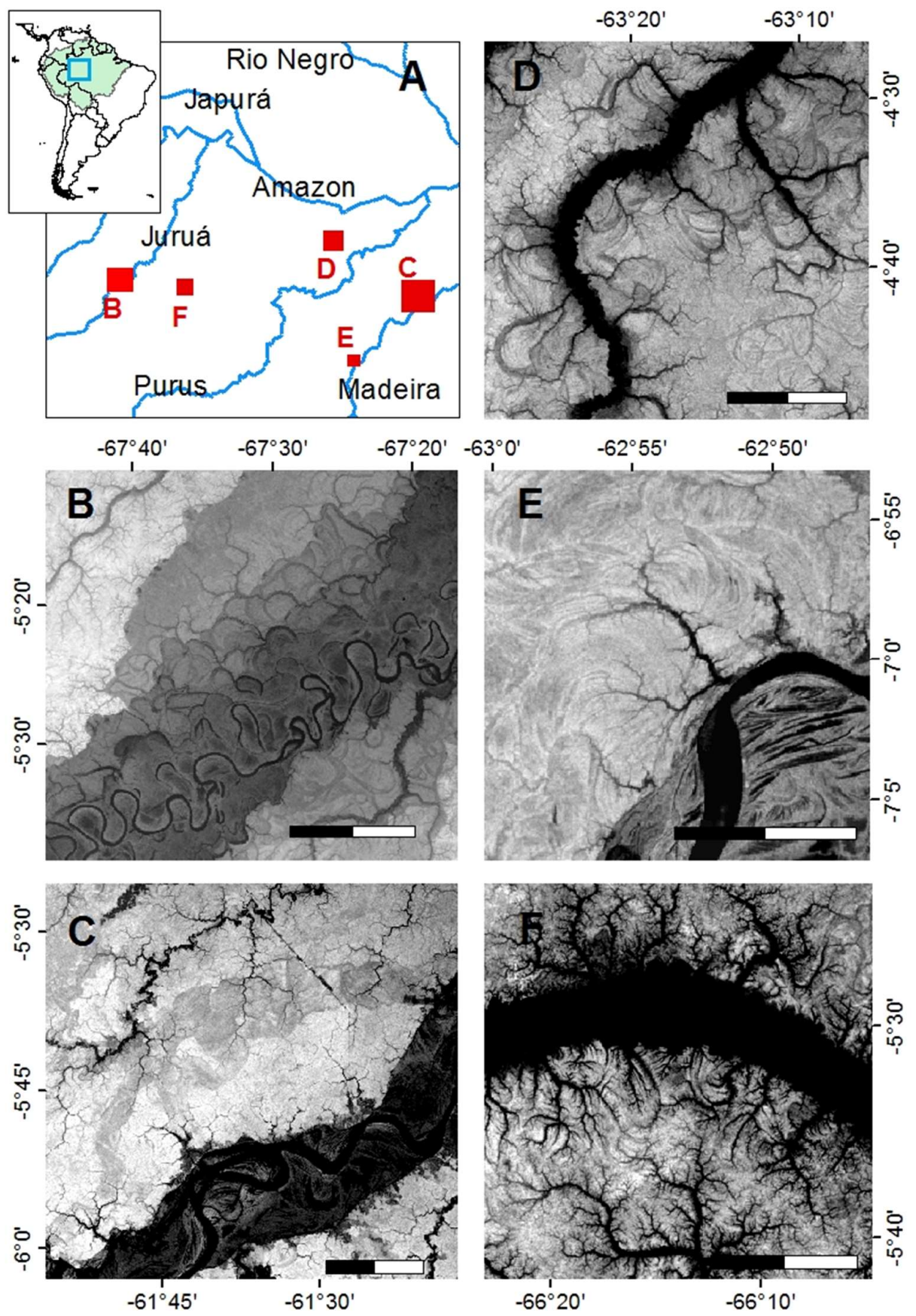

Fig. 1. Types of traces of fluvial activity in central Amazonian terra firme (noninundated) terrain as seen in the shuttle radar topography mission model (SRTM). The scale bar in each panel is $10 \mathrm{~km}$. A Index map. B Limits between river terraces are visible as sharp boundaries between topographically different levels, with the lower (younger) levels typically bearing traces of meanders and/or ridge-swale sequences. $\mathbf{C}$ A relict channel is visible as a long band of low-lying terrain north of the current river. We interpret this avulsion to have been so short-lived that the meander loops did not have time to completely close in on themselves and form oxbow lakes before the floodplain migrated again. D Curved depressions in terra firme correspond to abandoned meander loops of rivers that were considerably larger than those currently occupying them. E Parallel sequences of depressions and ridges in terra firme indicating scroll bars left behind by laterally advancing past river channels, similar to the ones in the current floodplain in the bottom-right corner. F Local drainage following the ridge-swale system and old meander loops of a large river that flowed on the southern side of the present west-to-east oriented blocked-valley river. 


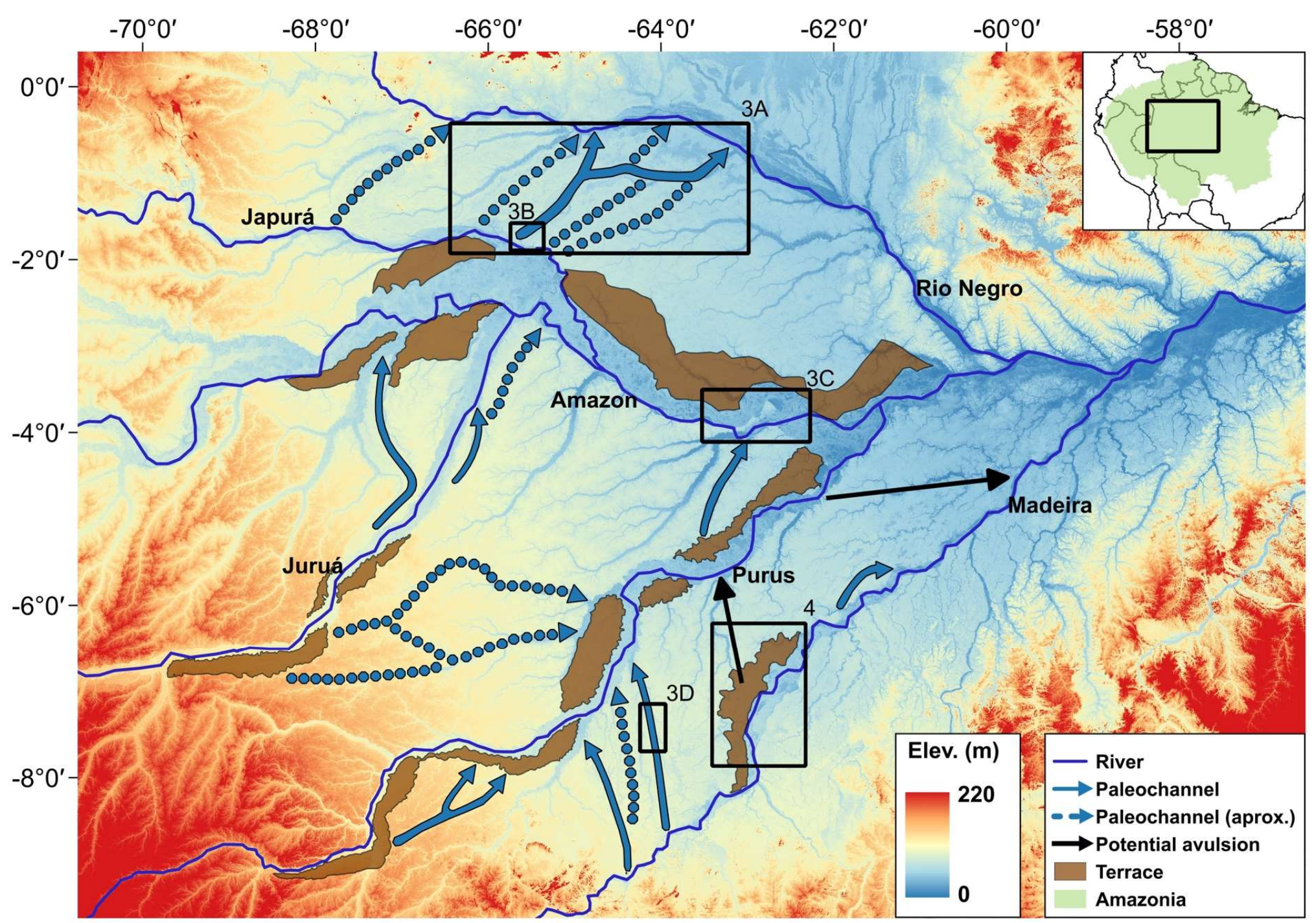

Fig. 2. Approximate routes of major avulsions within the last ca. 50 kyr of the rivers Japurá, Juruá, Purus and Madeira in central Amazonia based on marks of fluvial activity in present-day terra firme surface. The clearest fluvial marks, corresponding to more recent locations of the river channels, are indicated with solid lines and routes of higher uncertainty and greater age with dashed lines. The black solid lines indicate approximate routes of possible future avulsions. Major river terraces are highlighted in brown. The numbered boxes refers to the corresponding figures. 


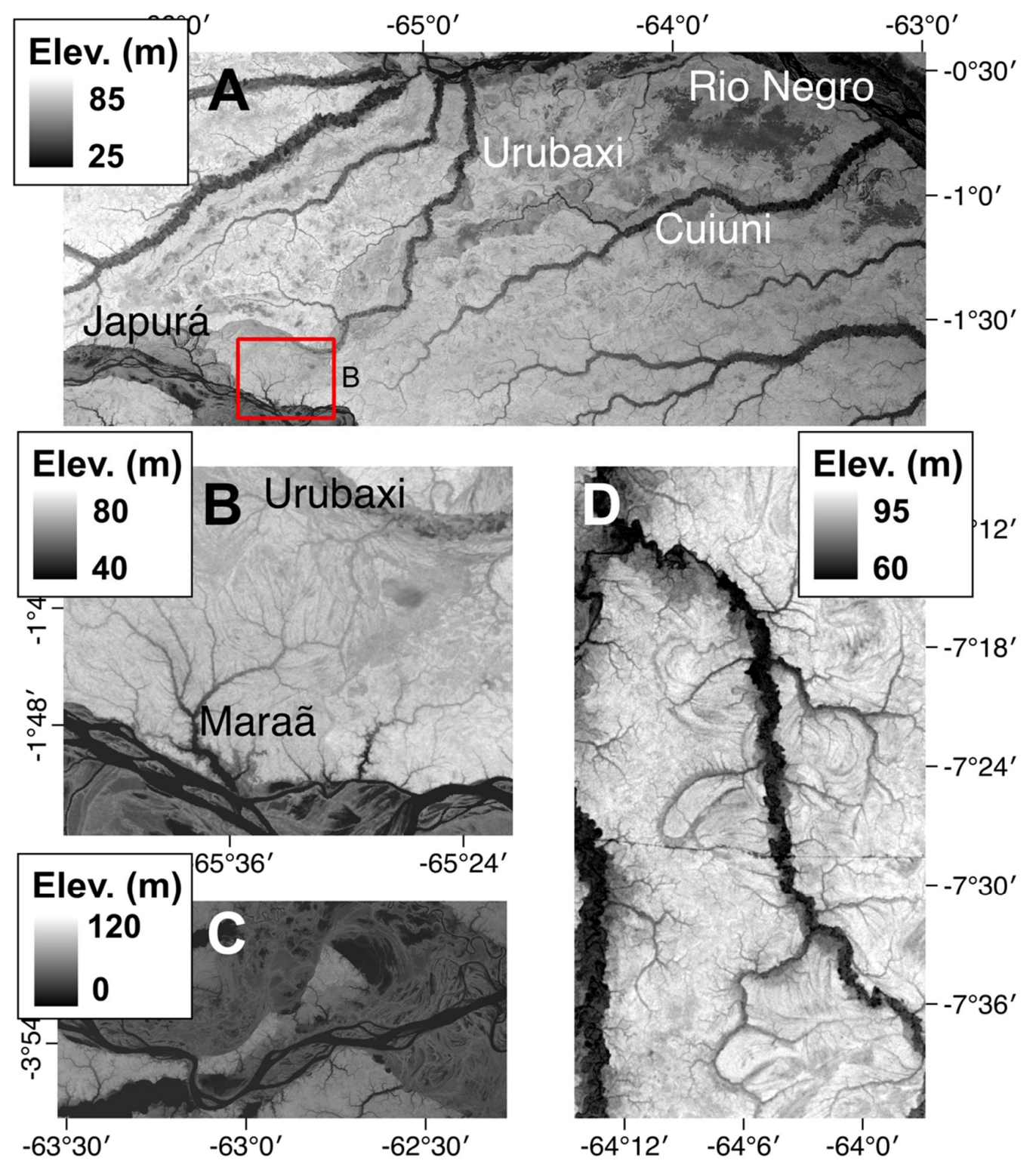

Fig. 3. Three examples of late Pleistocene-Holocene fluvial activity in central Amazonia. A Two relatively young paleochannels (with shared upper reaches) connecting the Japurá with Rio Negro. Currently these paleochannels are occupied by the Urubaxi and lower Cuiuni rivers. B The connection between the rivers Urubaxi (tributary of Rio Negro) and Marãa (tributary of Japurá). C A recent southward avulsion of the Amazon river channel that caused a 55-km-long stretch of terra firme to shift from the southern side of the river to its northern side. D Close-up along the river Açuã (tributary of the river Mucuím on the western edge of the map) of past meander loops of the paleo-Madeira from the time when it was flowing into the Purus in the north. The base map in all panels is the SRTM digital elevation model. 

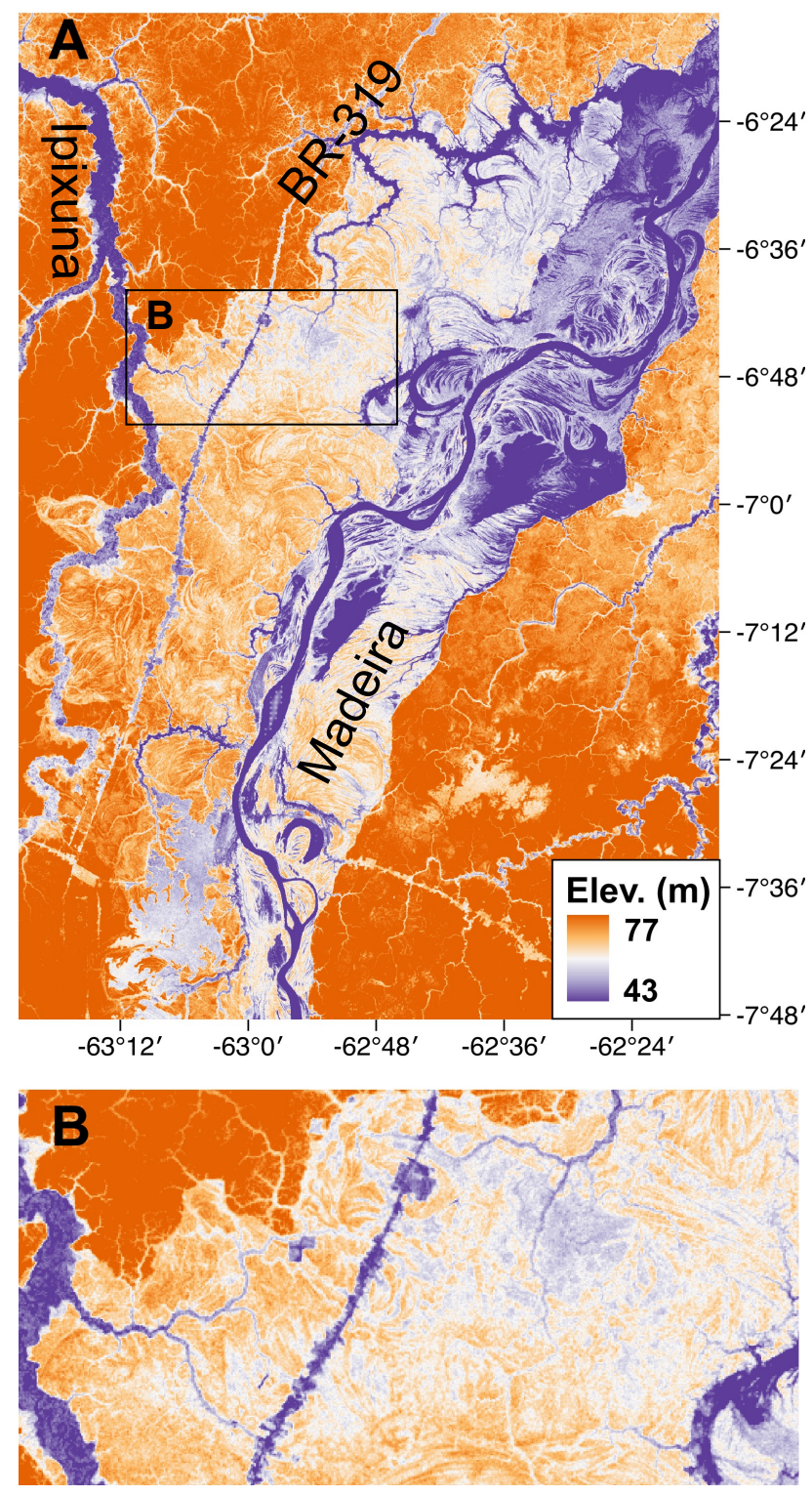

Fig. 4. The area of high avulsion risk of the Madeira river. The Ipixuna river, a tributary of the Purus, drains A the terrace of the Madeira river. The water division between the Madeira and the Ipixuna $\mathbf{B}$ lies at an approximate elevation of $45 \mathrm{~m}$ above sea level, deduced by the elevation of the road BR-319 traversing the area. The base map is the SRTM digital elevation model. 